\title{
The Smallest Aromatic Tetracation Produced in Gas Phase by Intense Femtosecond Laser Pulses
}

Akihiro Kitashoji, Akimasa Fujihara, Taiki Yoshikawa, Tomoyuki Yatsuhashi

\begin{tabular}{|c|c|}
\hline Citation & Chemistry Letters. 48(12); 1472-1475 \\
\hline Issue Date & 2019-12-05 \\
\hline Type & Journal Article \\
\hline Textversion & author \\
\hline Rights & $\begin{array}{l}\text { (C) } 2019 \text { The Chemical Society of Japan. All Rights Reserved. The following article } \\
\text { has been accepted by Chemistry Letters. After it is published, it will be found at } \\
\text { https://doi.org/10.1246/cl.190667. } \\
\text { Please cite only the published version. }\end{array}$ \\
\hline DOI & $10.1246 / \mathrm{cl} .190667$ \\
\hline Highlights & $\begin{array}{l}\text { ・芳香族 } 4 \text { 価陽イオンの最小サイズを } 34 \text { 年ぶりに更新 } \\
\text { ・大きな内部エネルギーや電子受容性を活かす化学反応の開発に期待 } \\
\text { ‘有機化合物初の } 5 \text { 価陽イオン・芳香族最小の } 4 \text { 価陽イオンの生成〜フェムト秒レーザーの } \\
\text { 活用によって〜'. 大阪市立大学. https://www.osaka-cu.ac.jp/ja/news/2019/191001-2. (参 } \\
\text { 照 2019-10-02) }\end{array}$ \\
\hline
\end{tabular}

\author{
Self-Archiving by Author(s) \\ Placed on: Osaka City University Repository
}

Akihiro Kitashoji, Akimasa Fujihara, Taiki Yoshikawa, Tomoyuki Yatsuhashi. (2019). The Smallest Aromatic Tetracation Produced in Gas Phase by Intense Femtosecond Laser Pulses. Chemistry Letters. 48, 1472-1475. doi:10.1246/cl.190667 


\title{
The Smallest Aromatic Tetracation Produced in Gas Phase by Intense Femtosecond Laser Pulses
}

\author{
Akihiro Kitashoji, ${ }^{1}$ Akimasa Fujihara, ${ }^{2}$ Taiki Yoshikawa, ${ }^{1}$ and Tomoyuki Yatsuhashi*1 \\ ${ }^{1}$ Graduate School of Science, Osaka City University, 3-3-138, Sugimoto, Sumiyoshi-ku, Osaka 558-8585, Japan \\ ${ }^{2}$ Graduate School of Science, Osaka Prefecture University, 1-1 Gakuen-cho, Naka-ku, Sakai, Osaka 599-8531, Japan
}

E-mail: tomo@sci.osaka-cu.ac.jp 3 aromatic tetracation ever investigated, by $0.8 \mu \mathrm{m}$ 4 femtosecond laser pulses. The tetracation yield relative to 5 that of trication radical is 0.11 . Using the time-of-flight 6 mass spectrometer equipped with the fast ion gate and the 7 curved field reflectron, we estimate the lower limit of the 8 lifetime of tetracation to be $9 \mu$ s. Confinement of multiple 9 positive charges in a small organic molecule is unexpected; 10 however, our finding is an answer of this fundamental 11 concern.

12 Keywords: multiply charged ion, time-of-flight mass spectrometry, tunnel ionization

Multiply charged ions are potentially different species compared with cations, anions, and neutral radicals. Macromolecules with several proton-accepting sites produce multiply protonated molecules $\left([\mathrm{M}+n \mathrm{H}]^{n+}\right)$ by electrospray ionization. ${ }^{1}$ Matrix-assisted laser desorption/ionization also forms multiply protonated molecules under specific conditions. $^{2}$ Since multiply protonated molecules are stable even-electron cations, fragmentation is initiated by acquiring a certain activation energy. On the other hand, the use of an intense femtosecond laser produces a different form of multiply charged ions, such as multiply charged molecular cations (MMCs, $\mathrm{M}^{z^{+}}$), by removing $z$ electrons via tunneling. ${ }^{3}$ MMCs are unstable due to their electron-deficient nature as well as strong Coulomb repulsions within MMCs regardless of whether they are formed as odd-electron cation radicals or even-electron cations. ${ }^{4}$ Therefore, intact MMCs have been little explored to date although they have the potential to be a reactive species due to their high electron affinity as well as high potential energy. ${ }^{5}$ In addition, investigations of intact MMCs provide an opportunity to understand how electron-deficient molecules maintain their chemical bonding. In this study, we describe the production of the smallest aromatic tetracation $\mathrm{C}_{6} \mathrm{~F}_{6}{ }^{4+}$ by femtosecond laser pulses.

The experimental details have been described elsewhere. ${ }^{6}$ Gaseous $\mathrm{C}_{6} \mathrm{~F}_{6}$ was ionized by focused linearly polarized femtosecond laser pulses delivered from a Ti:Sapphire laser $(0.8 \mu \mathrm{m}, 40 \mathrm{fs})$. The mass spectrum of $\mathrm{C}_{6} \mathrm{~F}_{6}$ (Figure 1a) taken by a Wiley-Mclaren time-of-flight mass spectrometer (TOF-MS) with a linear configuration (linTOF-MS) was dominated by MMCs $\left(\mathrm{C}_{6} \mathrm{~F}_{6}{ }^{2+}, z=1-4\right)$, which were definitively identified by their $\mathrm{m} / \mathrm{z}$ and isotopic structure. For example, a single peak appearing at $\mathrm{m} / \mathrm{z} 46.5$ and its accompanying single peak at $\mathrm{m} / \mathrm{z} 46.75$, shown in the inset of Figure 1a, were assigned to those of ${ }^{12} \mathrm{C}_{6} \mathrm{~F}_{6}{ }^{4+}$ and ${ }^{13} \mathrm{C}^{12} \mathrm{C}_{5} \mathrm{~F}_{6}{ }^{4+}$, respectively. The peak area of ${ }^{13} \mathrm{C}^{12} \mathrm{C}_{5} \mathrm{~F}_{6}{ }^{4+}$
51 relative to that of ${ }^{12} \mathrm{C}_{6} \mathrm{~F}_{6}{ }^{4+}$ was 0.070 (Figure $\mathrm{S} 1$ ), which is 52 close to the expected value $(0.066)$ calculated by the isotope 53 abundance and chemical composition within the 54 experimental error.
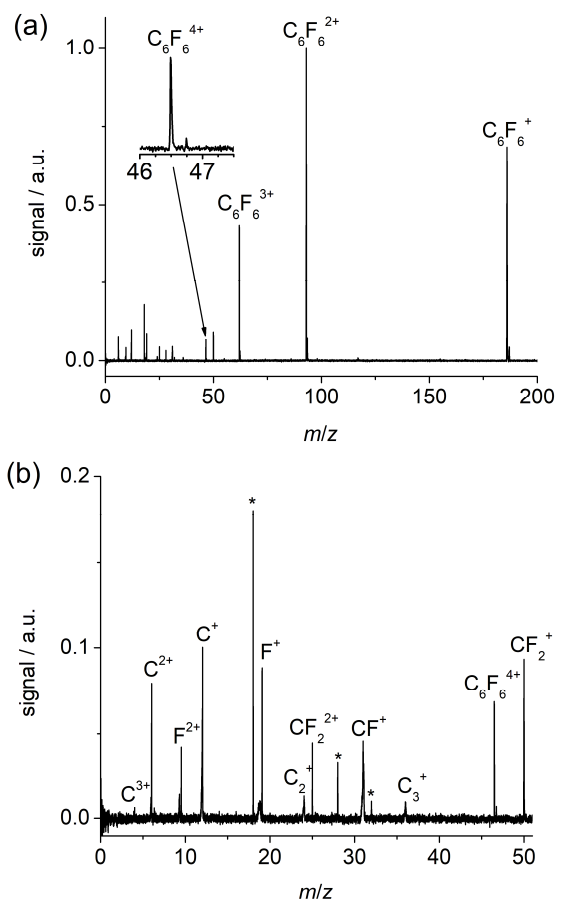

55

56 Figure 1. (a) Time-of-flight mass spectrum of $\mathrm{C}_{6} \mathrm{~F}_{6}\left(5 \times 10^{-5} \mathrm{~Pa}\right)$ 57 measured by linTOF-MS (BNG was not used, detected by MCP1, $V_{\mathrm{R}}=0$

$V)$. The inset shows the magnification of the tetracation peak. The laser intensity was $5.8 \times 10^{14} \mathrm{~W} \mathrm{~cm}^{-2}$. (b) Magnification of (a). * indicates the ion originating from contaminated water and air. saturation region. After reaching that region, the ion yield stayed constant or decreased, depending on the balance charge state and/or fragmentation. ${ }^{7}$ The appearance of as the point at which the ion yield (linear scale),
Figure $2 \mathrm{a}$ shows that the ion yield increased very steeply as laser intensity increased until it reached the between the increase of ions by the volume effect and the decrease of ions by the sequential ionization to a higher $\mathrm{C}_{6} \mathrm{~F}_{6}{ }^{2+}$ was evaluated by the saturation intensity, ${ }^{8}$ which is the index of ionization rate. Saturation intensity is defined extrapolated from the high-intensity linear portion of the curve, intersects the intensity axis (logarithmic scale) as shown in Figure 2b. Saturation intensities of $\mathrm{C}_{6} \mathrm{~F}_{6}{ }^{z+}$ were $1.1 \times 10^{14}(z=1), 1.2 \times 10^{14}(z=2), 2.1 \times 10^{14}(z=3)$, and $2.7 \times 10^{14} \mathrm{~W} \mathrm{~cm}^{-2}(z=4)$, respectively. The close proximity of saturation intensities and similar laser intensity 
1 dependences of MMC formation, despite their different

2 ionization energies, leads us to conclude that sequential 3 tunnel ionization processes rather than multiphoton 4 ionization processes are operative in MMC productions. ${ }^{9}$

(a)

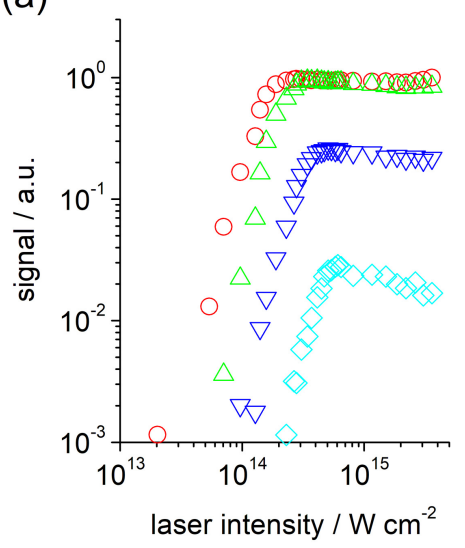

(b)
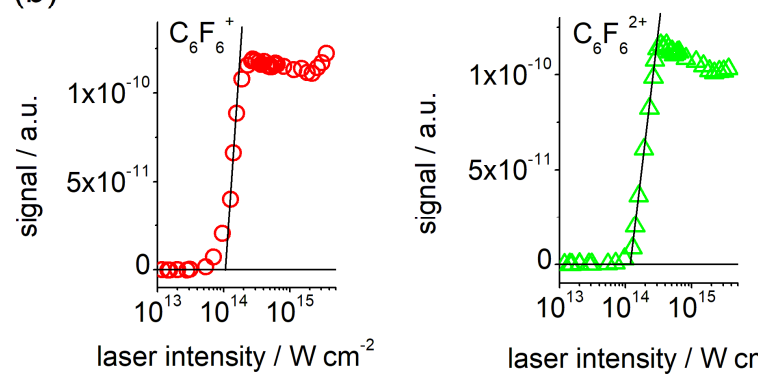

laser intensity $/ \mathrm{W} \mathrm{cm}^{-2}$
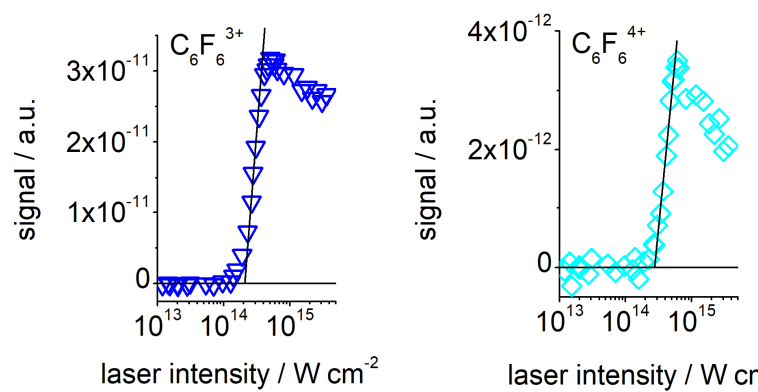

laser intensity / $\mathrm{W} \mathrm{cm}^{-2}$

6 Figure 2. Ion signal of $\mathrm{C}_{6} \mathrm{~F}_{6}$ as a function of laser intensity. (a)

7 log-log plot and (b) semilog plot: $\mathrm{C}_{6} \mathrm{~F}_{6}{ }^{+}$. (circles); $\mathrm{C}_{6} \mathrm{~F}_{6}{ }^{2+}$ (triangles);

$8 \mathrm{C}_{6} \mathrm{~F}_{6}{ }^{3+}$. (inverted triangles); $\mathrm{C}_{6} \mathrm{~F}_{6}{ }^{4+}$ (diamonds). The solid linear lines in

9 (b) are the extrapolation from the high-intensity linear portion of the

10 plots. The intersection with the intensity axis gives saturation intensity.

11 The $\mathrm{C}_{6} \mathrm{~F}_{6}$ pressure was $5 \times 10^{-5} \mathrm{~Pa}$. maximum charge number of $\mathrm{C}_{6} \mathrm{H}_{6}$ found under the same laser irradiation condition was 3 (not shown), although $\mathrm{C}_{6} \mathrm{H}_{6}$ is more likely to be tetracation from an energetic point of view. The vertical ionization energies of $\mathrm{C}_{6} \mathrm{H}_{6}$ and $\mathrm{C}_{6} \mathrm{~F}_{6}$ are 9.24 and $10.2 \mathrm{eV}$, respectively. ${ }^{10,11}$ Since the ionization energies required for further ionization of the cation radical as well as of dication are proportional to the first ionization energy, ${ }^{12}$ the multiple ionization of $\mathrm{C}_{6} \mathrm{H}_{6}$ is expected to be easier than that of $\mathrm{C}_{6} \mathrm{~F}_{6}$ from an energetic standpoint. Therefore, the abundance of $\mathrm{C}_{6} \mathrm{~F}_{6}$ tetracation owes to its stability, which in turn is due mainly to the absence of hydrogen atoms that are easily liberated as protons by Coulomb explosion. In 2011, the tetracation of the 4-atom molecule diiodoacetylene was found to be metastable due to the charge localization on the terminal iodine atoms. ${ }^{13}$ Based on knowledge about the previously reported tetracations, it is necessary to ensure minimum Coulomb repulsion by maximizing the distance between charges, presumably with the aid of structural deformation, ${ }^{14}$ in order to maintain the original chemical composition. High-level theoretical calculations using multi configurational method are required at least to understand how MMCs maintain their chemical bonding. ${ }^{15}$ However, such calculations are great challenges and beyond the scope of the present work.

MMCs dominated the mass spectrum of $\mathrm{C}_{6} \mathrm{~F}_{6}$, as shown in Figure 1a, but fragment ions $\left(\mathrm{C}_{2}{ }^{+}, \mathrm{CF}_{2}{ }^{2+}, \mathrm{CF}^{+}, \mathrm{C}_{3}{ }^{+}\right.$, $\left.\mathrm{CF}_{2}{ }^{+}, \mathrm{C}_{5} \mathrm{~F}_{3}^{+}\right)$and atomic ions $\left(\mathrm{C}^{3+}, \mathrm{C}^{2+}, \mathrm{F}^{2+}, \mathrm{C}^{+}, \mathrm{F}^{+}\right)$were also detected by a linTOF-MS (Figures 1b). Most of these fragment and atomic ions are not originated from $\mathrm{C}_{6} \mathrm{~F}_{6}{ }^{2+}(z=$ $1-4)$, but from higher charge states of $\mathrm{C}_{6} \mathrm{~F}_{6}$, which promptly dissociate by Coulomb explosion in the ion source. ${ }^{16}$ Nevertheless, there might be concern that ions can dissociate on the time-scale of TOF detection by metastable ion decay (MID). However, linTOF-MS measurements cannot discriminate the ions formed by MID from that formed by prompt dissociation in the ion source. Once MID of an MMC occurs after leaving the ion source, related product ions are not accelerated in the drift (field-free) region of a TOF-MS. Therefore, the precursor MMC and its product ions have the same velocity and thus the same arrival time to the ion detector (MCP1 in Figure 3) in the case of the linTOF-MS configuration. In order to measure the product ions of specific precursor ion, we first select an ion packet including a precursor MMC and related product ions by a Bradbury-Nielsen ion gate (BNG), which alters the flight path of the unwanted ions to the detector. ${ }^{17}$ The selected ion packet is further mass-separated by an offset curved field reflectron ${ }^{18}$, which can focus the product ions with different kinetic energy to the detector. The product ions originating from the MID of a particular precursor MMC are then detected by the second ion detector (MCP2 in Figure 3). It should be mentioned that the $\mathrm{m} / \mathrm{z}$ of measurable product ions is limited by that of the precursor ion. ${ }^{19}$

Figure 4 shows the product ion spectra of the selected MMC of ${ }^{12} \mathrm{C}_{6} \mathrm{~F}_{6}$. Spectra were taken under the elevated pressure of $\mathrm{C}_{6} \mathrm{~F}_{6}\left(5 \times 10^{-4} \mathrm{~Pa}\right)$ to improve the signal-to-noise ratio. As is clearly shown, product ions were not visible within the present signal-to-noise ratio range. This result 
1 reveals that the noticeable MID of MMCs does not occur

2 during the flight time in the drift region between the exit of 3 the ion source and the entrance of the reflectron: $18 \mu \mathrm{s}$ $4\left(\mathrm{C}_{6} \mathrm{~F}_{6}{ }^{+*}\right), 13 \mu \mathrm{s}\left(\mathrm{C}_{6} \mathrm{~F}_{6}{ }^{2+}\right), 10 \mu \mathrm{s}\left(\mathrm{C}_{6} \mathrm{~F}_{6}{ }^{3+\bullet}\right), 9 \mu \mathrm{s}\left(\mathrm{C}_{6} \mathrm{~F}_{6}{ }^{4+}\right)$.

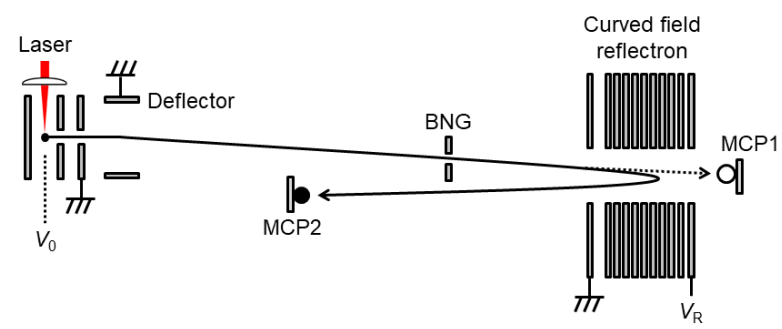

6 Figure 3. Schematic of TOF-MS (linTOF-MS, MCP1 is used, $V_{\mathrm{R}}=0$ $7 \mathrm{~V}$; refTOF-MS, MCP2 is used, $V_{\mathrm{R}}=3865 \mathrm{~V}$ ). $V_{0}$ is fixed to $2740 \mathrm{~V}$.
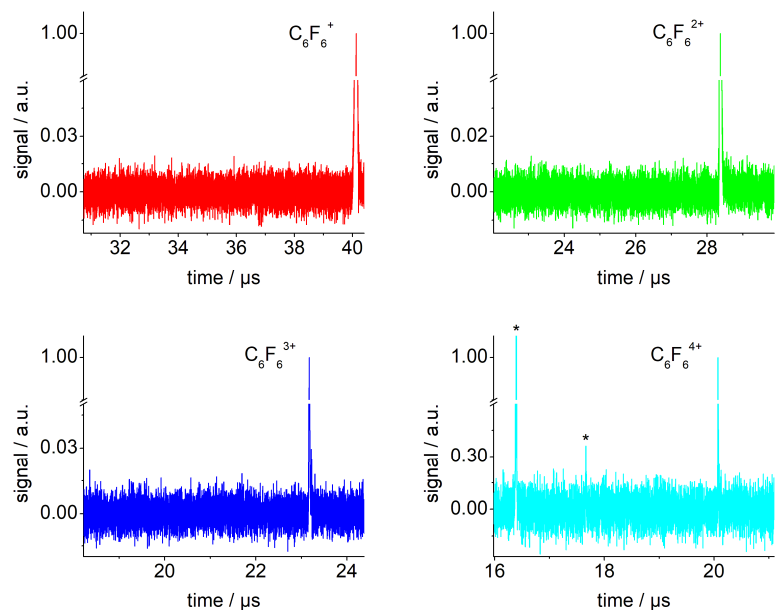

10 Figure 4. Time-of-flight spectra of particular ${ }^{12} \mathrm{C}_{6} \mathrm{~F}_{6}{ }^{z+}$ measured by series of perfluoroaromatics, is necessary to show the trends about the production and stability of tetracations. Although the definitive conclusion cannot be made because the yield of MMCs is not only dependent on the ionization processes and thermodynamic stability but also photoreactivity, the charge delocalization over the aromatic moiety might determine the stability of tetracations based on the comparison between $\mathrm{C}_{6} \mathrm{~F}_{6}$ and $\mathrm{C}_{10} \mathrm{~F}_{8}$. Theoretical considerations about the electronic states of a series of perfluoroaromatic molecules are in progress.

The present research was partially supported by JST PRESTO program and JSPS KAKENHI Grant Number JP26107002 in Scientific Research on Innovative Areas "Photosynergetics." We thank Mr. Kazuhiko Kondo of Thales Japan Inc. for his kind contribution to our laser system.

Supporting Information is available on http://dx.doi.org/10.1246/cl.******.

\section{References and Notes}

Fenn, J. B.; Mann, M.; Meng, C. K.; Wong, S. F.; Whitehouse, C. M. Science 1989, 246, 64-71; McLuckey, S. A.; Stephenson, J. L. Mass Spectrom. Rev. 1998, 17, 369-407; Pitteri, S. J.; McLuckey, S. A. Mass Spectrom. Rev. 2005, 24, 931-958.

2 Koch, A.; Schnapp, A.; Soltwisch, J.; Dreisewerd, K. Int. J. Mass Spectrom. 2017, 416, 61-70; Cramer, R.; Pirk1, A.; Hillenkamp, F.; Dreisewerd, K. Angew. Chem. Int. Ed. 2013, 52, 2364-2367; McEwen, C. N.; Pagnotti, V. S.; Inutan, E. D.; Trimpin, S. Anal. Chem. 2010, 82, 9164-9168.

3 Ledingham, K. W. D.; Singhal, R. P.; Smith, D. J.; McCanny, T.; Graham, P.; Kilic, H. S.; Peng, W. X.; Wang, S. L.; Langley, A. J.; Taday, P. F.; Kosmidis, C. J. Phys. Chem. A 1998, 102, 3002-3005

4 Nakashima, N.; Shimizu, S.; Yatsuhashi, T.; Sakabe, S.; Izawa, Y. J. Photochem. Photobiol. C 2000, 1, 131-143; Yatsuhashi, T.; Nakashima, N. J. Photochem. Photobiol. C 2018, 34, 52-84.

5 Mathur, D. Phys. Rep. 1993, 225, 193-272; Mathur, D. Phys. Rep. 2004, 391, 1-118; Schröder, D. Angew. Chem. Int. Ed. 2004, 43, 1329-1331; Schröder, D.; Schwarz, H. J. Phys. Chem. A 1999, 103, 7385-7394; Vekéy, K. Mass Spectrom. Rev. 1995, 14, 195-225.

6 Mitsubayashi, N.; Yatsuhashi, T.; Tanaka, H.; Furukawa, S.; Kozaki, M.; Okada, K.; Nakashima, N. Int. J. Mass Spectrom. 2016, 403, 43-52.

Yatsuhashi, T.; Obayashi, T.; Tanaka, M.; Murakami, M.; Nakashima, N. J. Phys. Chem. A 2006, 110, 7763-7771.

8 Hankin, S. M.; Villeneuve, D. M.; Corkum, P. B.; Rayner, D. M. Phys. Rev. Lett. 2000, 84, 5082-5085; Murakami, E.; Mizoguchi, R.; Yoshida, Y.; Kitashoji, A.; Nakashima, N.; Yatsuhashi, T. J. Photochem. Photobiol. A 2019, 369, 16-24.

9 Nagaya, K.; Mineo, H.; Mishima, K.; Villaeys, A. A.; Hayashi, M.; Lin, S. H. Phys. Rev. A 2007, 75, 013402.

10 Nemeth, G. I.; Selzle, H. L.; Schlag, E. W. Chem. Phys. Lett. 1993, 215, 151-155.

11 Bieri, G.; Asbrink, L.; Vonniessen, W. J. Electron. Spectrosc. Relat. Phenom. 1981, 23, 281-322.

12 Tobita, S.; Leach, S.; Jochims, H. W.; Ruhl, E.; Illenberger, E.; Baumgartel, H. Can. J. Phys. 1994, 72, 1060-1069; Yatsuhashi, T.; Nakashima, N. J. Phys. Chem. A 2005, 109, 9414-9418.

13 Yatsuhashi, T.; Mitsubayashi, N.; Itsukashi, M.; Kozaki, M.; Okada, K.; Nakashima, N. ChemPhysChem 2011, 12, 122-126; 
Yatsuhashi, T.; Toyota, K.; Mitsubayashi, N.; Kozaki, M.; Okada, K.; Nakashima, N. ChemPhysChem 2016, 17, 2977-2981.

14 Ibrahim, K.; Lablanquie, P.; Hubinfranskin, M. J.; Delwiche, J.; Furlan, M.; Nenner, I.; Hagan, D.; Eland, J. H. D. J. Chem. Phys. 1992, 96, 1931-1941.

15 Hammami, H.; Yazidi, O.; Rhouma, M. B.; Al Mogren, M. M.; Hochlaf, M. J. Chem. Phys. 2014, 141, 014302.

16 Shimizu, S.; Zhakhovskii, V.; Murakami, M.; Tanaka, M.; Yatsuhashi, T.; Okihara, S.; Nishihara, K.; Sakabe, S.; Izawa, Y.; Nakashima, N. Chem. Phys. Lett. 2005, 404, 379-383.

17 Kitashoji, A.; Yoshikawa, T.; Fujihara, A.; Kamamori, T.; Nashima, S.; Yatsuhashi, T. ChemPhysChem 2017, 18, 2007-2011.

18 Nikolaev, E. N.; Somogyi, A.; Smith, D. L.; Gu, C. G.; Wysocki, V. H.; Martin, C. D.; Samuelson, G. L. Int. J. Mass Spectrom. 2001, 212, 535-551; Satoh, T.; Sato, T.; Kubo, A.; Tamura, J. J. Am. Soc. Mass. Spectrom. 2011, 22, 797-803; Shimma, S.; Kubo, A.; Satoh, T.; Toyoda, M. Plos One 2012, 7, e37107.

19 Demirev, P. A.; Feldman, A. B.; Kowalski, P.; Lin, J. S. Anal. Chem. 2005, 77, 7455-7461; Liu, Z. L.; Schey, K. L. J. Am. Soc. Mass. Spectrom. 2008, 19, 231-238.

20 Bursey, M. M.; Rogerson, P. F.; Bursey, J. M. Org. Mass Spectrom. 1970, 4, 615-617.

21 Kingston, R. G.; Guilhaus, M.; Brenton, A. G.; Beynon, J. H. Org. Mass Spectrom. 1985, 20, 406-412.

22 Yatsuhashi, T.; Nakashima, N. J. Phys. Chem. A 2010, 114, 7445-7452.

23 Kitashoji, A.; Yatsuhashi, T. Chem. Phys. 2019, 526, 110465.

24 Lawicki, A.; Holm, A. I. S.; Rousseau, P.; Capron, M.; Maisonny, R.; Maclot, S.; Seitz, F.; Johansson, H. A. B.;. Rosén, S.; Schmidt, H. T.; Zettergren, H.; Mvanil, B.; Adoui, L.; Cederquist, H.; Huber, B. A. Phys. Rev. A 2011, 83, 022704; Rousseau, P.; Lawicki, A.; Holm, A. I. S.; Capron, M.; Maisonny, R.; Maclot, S.; Lattouf, E.; Johansson, H. A. B.; Seitz, F.; Mery, A.; Rangama, J.; Zettergren, H.; Rosen, S.; Schmidt, H. T.; Chesnel, J. Y.; Domaracka, A.; Manil, B.; Adoui, L.; Cederquist, H.; Huber, B. A. Nucl. Instrum. Meth. B 2012, 279, 140-143. 
NOTE The diagram is acceptable in a colored form. Publication of the colored G.A. is free of charge. For publication, electronic data of the colored G.A. should be submitted. Preferred data format is EPS, PS, CDX, PPT, and TIFF. If the data of your G.A. is "bit-mapped image" data (not "vector data"), note that its print-resolution should be 300 dpi.

You are requested to put a brief abstract (50-60words, one paragraph style) with the graphical abstract you provided, so that readers can easily understand what the graphic shows.

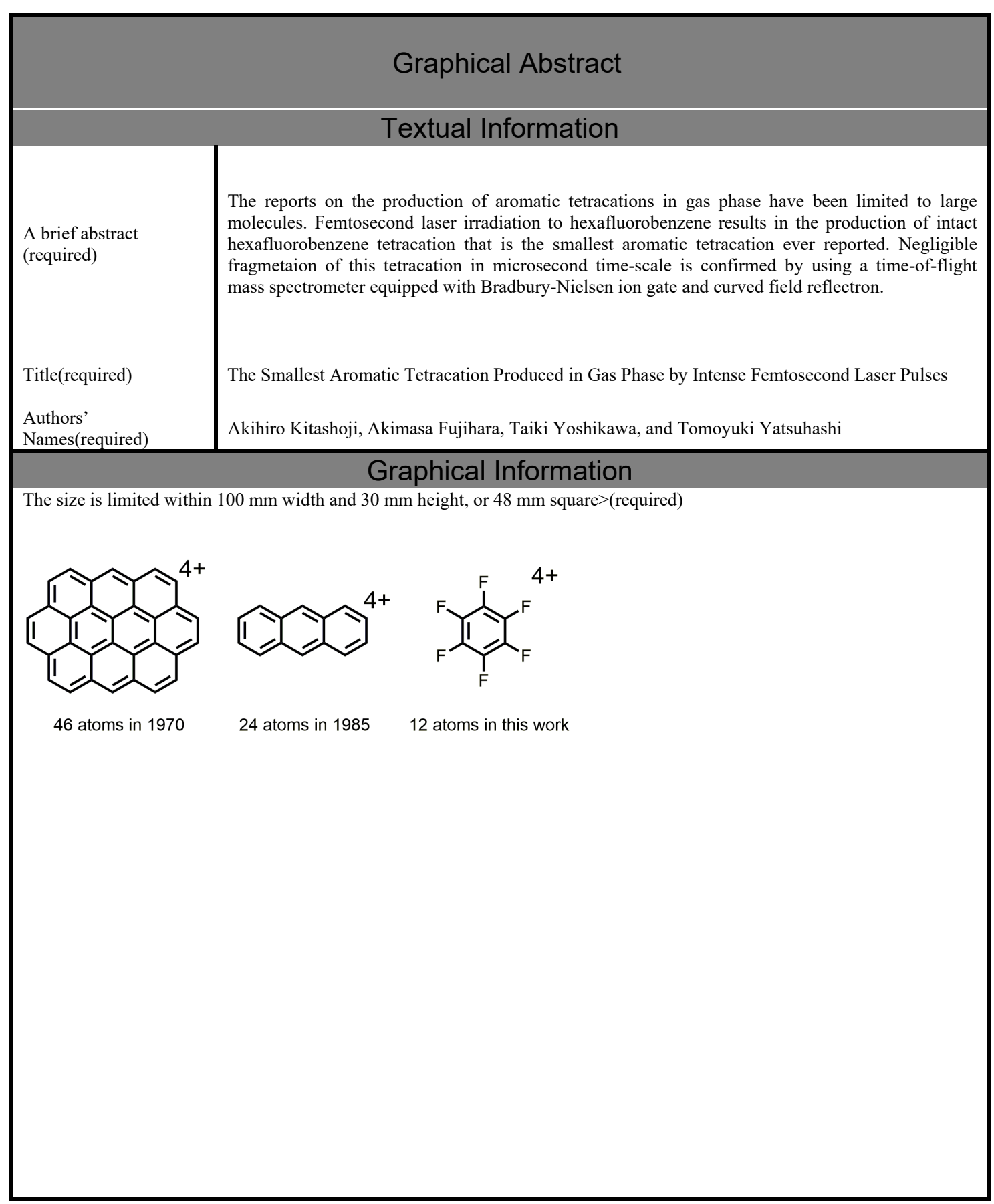

